\title{
ADVANCED DE-ICING SYSTEM OF REGIONAL AIRCRAFT
}

Ua Розроблено методологію розрахунку параметрів пневматичної протиобледенювальної системи літаків. Вона включає визначення зон захисту, розрахунок системи наддуву протекторів, розрахунок системи вакуумування протекторів. Розраховані параметри протиобледенювальної системи на прикладі регіонального літака Ан-140. Наведений порівняльний аналіз параметрів традиційної повітряно-теплової протиобледенювальної системи i пневматичної протиобледенювальної системи показав ефективність останньої для регіональних літаків. Розроблена методологія може використовуватися при проектуванні протиобледенювальної системи літаків.

Ru Разработана методология расчета параметров пневматической противообледенительной системы самолетов. Она включает определение зон защиты, расчет системы наддува протекторов, расчет системы вакуумирования протекторов. Рассчитаны параметры противообледенительной системы на примере регионального самолета Ан-140. Приведенный сравнительный анализ параметров традиционной воздушно-тепловой противообледенительной системы и пневматической противообледенительной системы показал эффективность последней для региональных самолетов. Разработанная методология может использоваться при проектировании противообледенительной системы самолетов.

\section{Statement of problem}

Ice is flying longtime enemy. Under certain atmospheric conditions, ice can be built rapidly on airfoils. On days when there is visible moisture in the air, ice can be formed on aircraft leading edge surfaces at altitudes where freezing temperature start. Water droplets in the air can be supercooled to below freezing without actually turning into ice unless they are disturbed in some manner. This unusual occurrence is partly due to the surface tension of the water droplet not allowing the droplet to expand and freeze. However, when aircraft surface disturbs these droplets, they immediately turn to the ice on the aircraft surface. Inflight icing destroys the smooth flow of air, increasing drag and decreasing the ability of an airfoil to lift. Ice accumulates on every exposed frontal surface of the aeroplane - the wings, stabilizer, propeller, windshield, antennas, vents, intakes, and cowlings. Sharp components such as thin leading edges of wing and stabilizer gather ice more readily than other components. The resulting malfor-

\footnotetext{
${ }^{1}$ Igor Sikorsky Kyiv Polytechnic Institute

${ }^{2}$ Igor Sikorsky Kyiv Polytechnic Institute
} 
mation of the airfoil could decrease both maximum lift coefficient and critical angle of attack [Fig. 1].

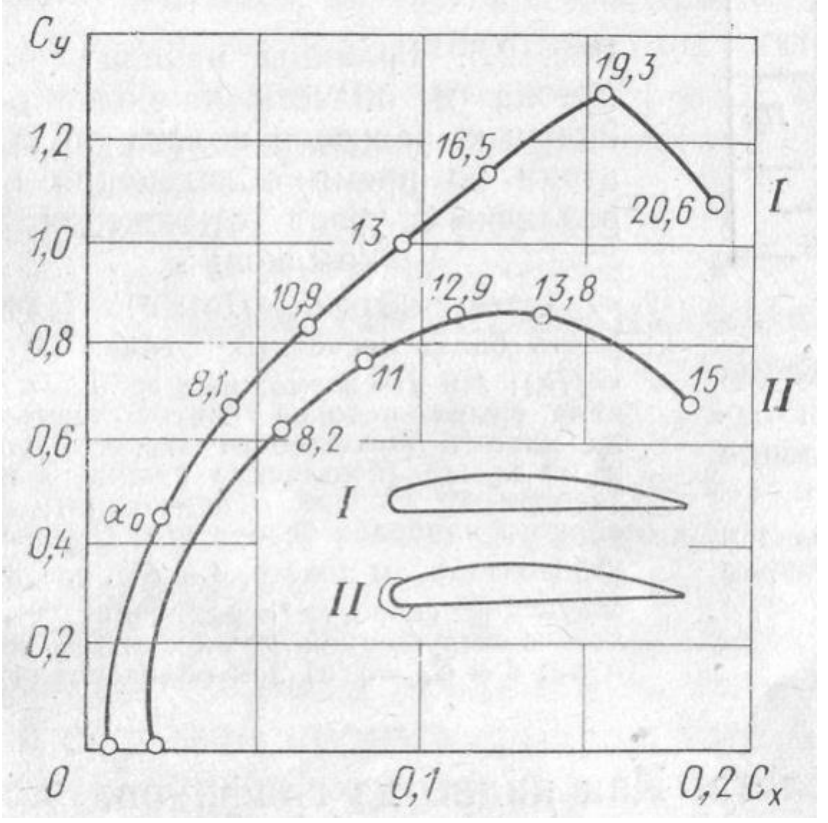

Fig. 1. Influence of icing: I - clean wing; II - icing wing

Ice formations at stabilizer can lead to stall at little wing angle of attack [Fig. 2]. So designing of effective deicing systems of wing and stabilizer is actual problem.

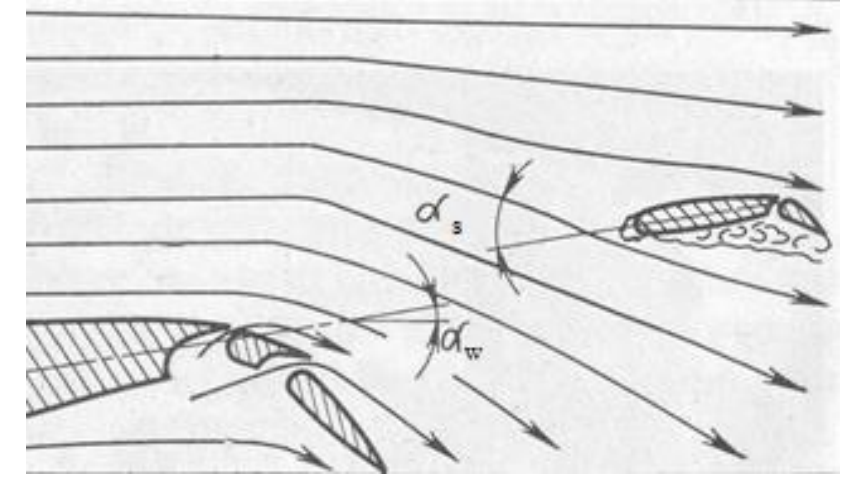

Fig. 2. Stall at stabilizer

\section{Analysis of last achievements and publications}

The problem of flights in icing conditions appears in the late 1920s, when it was a matter of flying 24 hours a day all weather conditions. An active study of aircraft flights in icing conditions began in the 30s of the twentieth century. Despite the fact that almost everything is known about flights in icing conditions, icing remains a dangerous factor that occasionally leads to accidents. Investigations of flights in icing conditions include investigations of icing conditions $[1,5,6,7,8,9]$, effects of ice accretions on aircraft aerodynamics 


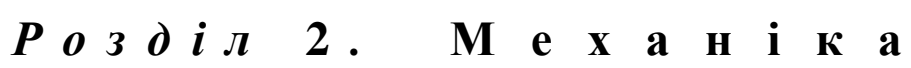

[3, 5 - 20], airworthiness requirements, accident investigation $[7,8]$, recommendations for de-icing $[2,3,4,5,9,18]$.

\section{Formulation of purpose}

Icing can occur at different parts of aircraft: wing, tail, propeller, racks, cables, navigation aids. However, the most dangerous is icing on wing and horizontal stabilizer. Depending on the type, characteristics and purpose of aircraft, the best method and anti-icing system is selected. Currently, the following antiicing systems are available: pneumatic, electrical thermal, electro-pulse, liquid, and air-thermal. Each system has advantages and disadvantages. Choice of antiicing system type is a complex engineering task that requires many factors to be considered. All anti-icing systems are divided into systems of continuous and cyclic action. Anti-icing systems of continuous action prevent the ice formation during flight. Cyclic de-icing systems allow the ice formation to a certain thickness, and then remove the ice (economy mode).

Pneumatic de-icing systems have relatively low mass and energy intensity. The principle of operation of the pneumatic de-icing system is shown in Fig. 3. Pneumatic de-icing boots of flexible material with pneumatic tubes is fixed on the protected surface. Air under pressure is supplied inside boots in a certain order. When the air is supplied, the boots inflate, tear and split the ice, which is carried away by the incoming stream from the protected surface [Fig. 4].

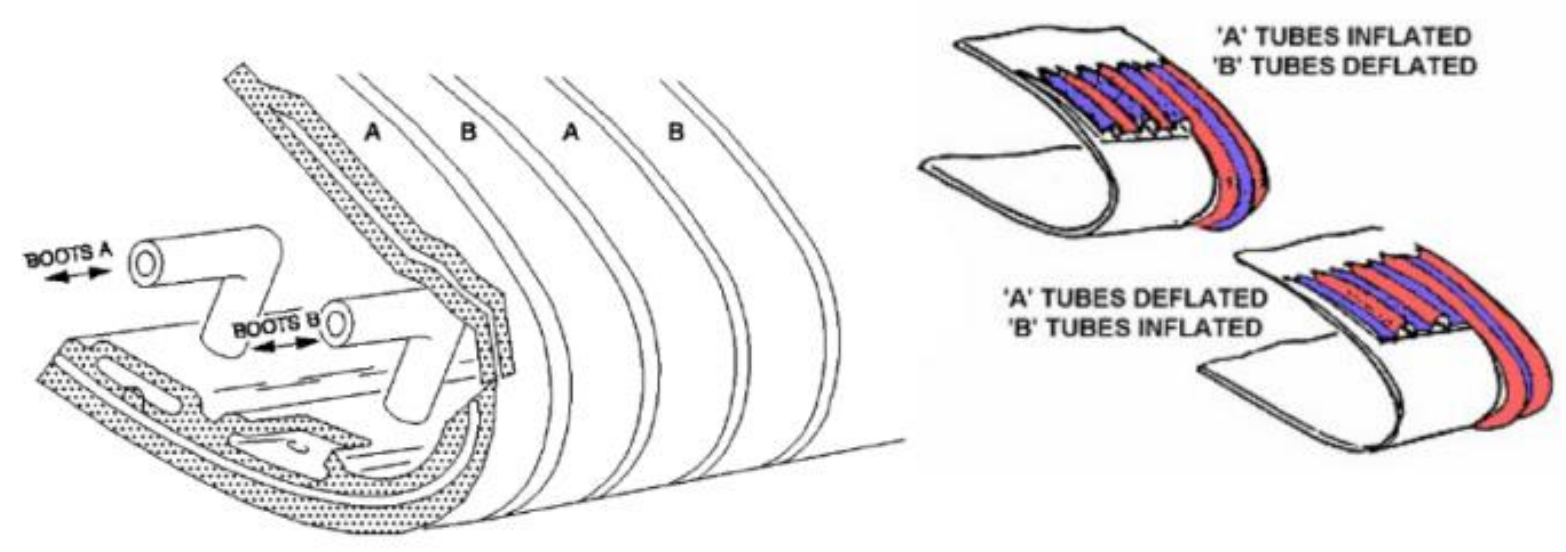

Fig. 3. Inflation of boots

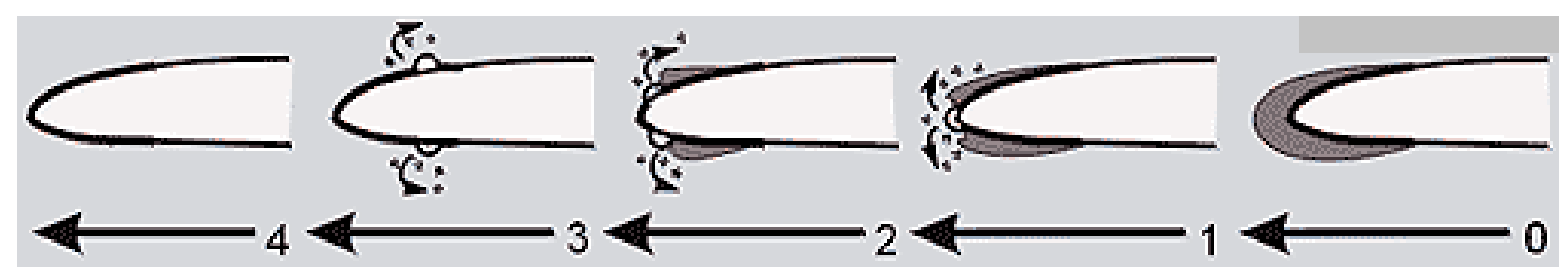

Fig. 4. Action of pneumatic de-icing system 


\section{Presentation of basic material}

Calculation of airframe pneumatic de-icing system includes stages: determination of protection zones, calculation of boot pressurizing system, and calculation of boot depression system. Pneumatic de-icing system of the regional aircraft An-140 was considered and calculated [Fig. 5].

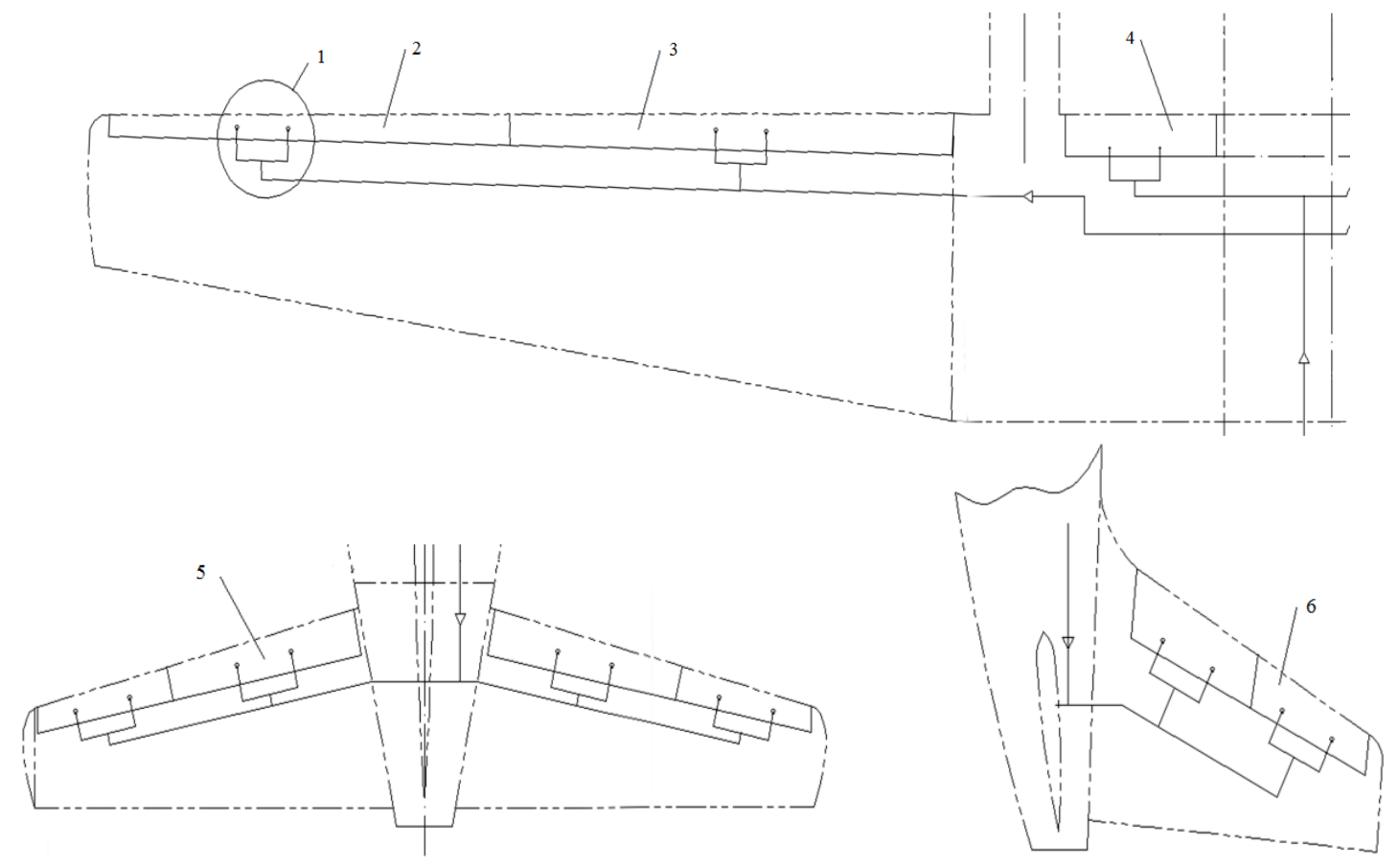

Fig. 5. Schematic diagram of pneumatic de-icing system:

1 - connection for supplying air to the boot; 2,3 - boot of the wing leading edge; 4 - boot of the centre wing section; 5 - stabilizer boot; 6 - fin boot

\section{Determination of protection zones}

According to airworthiness requirements, such values of parameters were taken: liquid water content $=0,7 \mathrm{~g} / \mathrm{m}^{3}$; drop diameter $=20 \mathrm{~mm}$; altitude $=3000 \mathrm{~m}$; temperature of outside air $=-5^{\circ} C$; airspeed $=520 \mathrm{~km} / \mathrm{h}$; coefficient of lift $=0,8$. Capture on the wing will be on the upper surface $170 \mathrm{~mm}$ and on the lower surface $120 \mathrm{~mm}$. The protection zone is accepted: on the upper surface $112 \mathrm{~mm}$; on the lower surface $129 \mathrm{~mm}$. The area occupied by boot is assumed: on the upper surface $150 \mathrm{~mm}$; on the lower surface $170 \mathrm{~mm}$. Such values are taken for fin and stabilizer.

Airframe protection along the wingspan: center wing $2640 \mathrm{~mm}$; wing leading edge of the 1 st section $4260 \mathrm{~mm}$; wing leading edge wing of the 2-nd section $4258 \mathrm{~mm}$; total $22316 \mathrm{~mm}$. Protection of tail: stabilizer (2) $4080 \mathrm{~mm}$; fin $3900 \mathrm{~mm}$. 


\section{Calculation of boot pressurizing system}

The inflation area is determined as the segment area:

$$
\begin{gathered}
S_{i}=\frac{1}{2}\left[L_{s} R_{s}-a\left(R_{s}-H_{s}\right)\right]=\frac{1}{2}[2,98 \cdot 2-2(2-0,7)]=1,47 \mathrm{~cm}^{2} \\
L_{s}=\sqrt{a^{2}+16 / 3 \cdot H_{S}^{2}}=\sqrt{2,5^{2} \cdot 16 / 3 \cdot 0,7^{2}}=2,98 \mathrm{~cm}^{2},
\end{gathered}
$$

where $L_{s}$ is the length of the segment arc; $R_{s}$ is the segment radius; $H_{s}$ is the segment height; a is the segment chord.

An air volume for inflation is calculated by the formula

$$
V_{B}=\left(L_{C} / A_{\mathrm{II}}\right) \cdot S_{i} \cdot L_{z},
$$

where $L_{C}$ is the section length; $L_{Z}$ is the length of protection zone; $A_{\mathrm{n}}$ is boot step, $30 \mathrm{~mm}$.

The initial data for the volume calculations and the results of the calculations are shown in Table 1.

Table 1.

\begin{tabular}{|l|l|c|c|c|c|c|c|}
\hline No & Name & $\begin{array}{c}\text { Section } \\
\text { length } \\
L_{s}, \mathbf{c m}\end{array}$ & $\begin{array}{c}\text { Protec- } \\
\text { tion zone } \\
L_{Z}, \mathbf{c m}\end{array}$ & $\begin{array}{c}\text { Number } \\
\text { of steps } \\
n\end{array}$ & $\begin{array}{c}\text { Air } \\
\text { volume } \\
V_{B}, \mathbf{l}\end{array}$ & $\begin{array}{c}\text { Boot } \\
\text { length } \\
L_{b}\end{array}$ & $\begin{array}{c}S_{b}, m^{2} \cdot 10^{-2} \\
\text { Boot area }\end{array}$ \\
\hline & $\begin{array}{l}\text { End } \\
\text { Section }\end{array}$ & 425,8 & 23 & 141 & 4,9 & 33 & 1,405 \\
& $\begin{array}{l}\text { Center } \\
\text { wing }\end{array}$ & 264,0 & 23 & 88 & 3,1 & 33 & 0,871 \\
3 & Stabilizer & 488,0 & 21 & 136 & 4,7 & 31 & 1,510 \\
4 & Fin & 390,0 & 19 & 130 & 4,5 & 29 & 1,130 \\
5 & $\begin{array}{l}\text { Root } \\
\text { section }\end{array}$ & 426,0 & 23 & 142 & 5,0 & 33 & 1,406
\end{tabular}

In order to avoid deterioration in aircraft aerodynamic performance an air distribution by consumers was organized as follows: end section and root sections of the wing leading edge $V_{1}=(4,9+5) \cdot 2=19,8$ litres; center wing $V_{2}=3,1 \cdot 2=6,2$ litres; stabilizer and fin $V_{3}=4,5+4,7 \cdot 2=13,9$ litres ; supplying pipelines $V_{4}=0,00314 \cdot 863=2,7$ litres. Total air volume is

$$
V_{1}=V_{1}+V_{2}+V_{3}+V_{4}=19,8+6,2+13,9+2,7=43 \text { litres. }
$$

The air density in the boot

$$
\Gamma=\mathrm{P} / R T=2,4 \cdot 1000 / 29,2 \cdot 310=2,75 \mathrm{~kg}^{3} / \mathrm{m}=0,00275 \mathrm{~kg} / \text { litre, }
$$

where $P=2,4 \mathrm{~kg} / \mathrm{cm}$ is pressure in the boots; $R=29,27$ is gas constant; $T=300^{\circ} \mathrm{K}=23^{\circ} \mathrm{C}$ is air temperature.

The mass of the required air for 1 cycle is: $M_{1}=19,8$ liters $\cdot 0,00275 \mathrm{~kg} /$ liters $=0,05445 \mathrm{~kg}$; 
$M_{2}=6,2$ liters $\cdot 0,00275 \mathrm{~kg} /$ liters $=0,01705 \mathrm{~kg}$;

$M_{3}=13,9$ liters $\cdot 0,00275 \mathrm{~kg} /$ liters $=0,03822 \mathrm{~kg}$;

$M_{4}=2,7$ liters $\cdot 0,00275 \mathrm{~kg} /$ liters $=0,0074 \mathrm{~kg}$; total is $0,1171 \mathrm{~kg}$.

Consumption of air during the cycle ( $5 \mathrm{sec}$ of inflate and $55 \mathrm{sec}$ of pumping) is $G=0,1171 \mathrm{~kg} / 5 \mathrm{~s}=0,023 \mathrm{~kg} / \mathrm{s}$.

Selected vacuum pump 5866 has good performance, low mass, low power consumption and is appropriate for this system.

\section{Calculation of boot depression system}

For satisfactory operation of the pneumatic de-icing system, it is necessary to provide appropriate air pressure in the pipelines. For this purpose hydraulic calculation is performed.

The pressure loss in the lateral channels is calculated by the formula $\Delta p_{k}=\left(\zeta_{\text {in }}+\mathrm{c}_{f} \cdot \frac{l}{d_{g}}\right) \cdot \frac{\varrho V_{k}^{2}}{2} \cdot N / m^{2}, \zeta_{\text {in }}$ is input loss factor; $\mathrm{c}_{f}-$ is coefficient of friction.

Pressure drop in the longitudinal air channel along the leading edge is $\Delta p_{k}=\mathrm{c}_{f} \cdot \frac{\varrho V_{k}^{2}}{2} \cdot \frac{l}{d_{g}} \cdot N / m^{2}$. If the lateral channels are in the form of double skin, then the value of the friction coefficient is $c_{\mathrm{f}}=0,184 / \mathrm{R}_{\mathrm{e}}^{0,2}$.

The pressure loss on straight sections of pipelines that supply air to the protected surface is calculated by the formula $\Delta p_{k}=\sum_{i=1}^{n} \cdot\left(\zeta_{i}+f_{i} \cdot l / d_{\mathrm{p}}\right) \cdot \varrho_{i} V_{i}^{2} / 2$.

Assume that at the beginning of the pipeline the velocity is greater than at the end before the last hole, that is $V_{\text {beg }}>V_{\text {end }}$. For constant static pressure along the entire length of the line, it is necessary to maintain $\varrho V_{\text {beg }}{ }^{2} / 2-\varrho V_{\text {end }}{ }^{2} / 2=\sum\left(\Delta p_{\mathrm{p}}+\Delta p_{l}\right)$, where $\Delta p_{\mathrm{p}}$ is the total loss of friction pressure along the length of the distribution pipe, $\Delta p_{l}$ is pressure loss in local resistances of all pipeline holes. For simplicity of calculation, it was assumed that the pipeline diameters so that the air velocity after each hole decreases with the same value $\Delta V=\frac{V_{b e g}-V_{\text {end }}}{n}$, where $\mathrm{n}$ is the number of pipeline holes. The pressure loss between the adjacent holes due to the velocity change during flow division will be equal $\Delta p=1 / 3 \cdot\left(V_{\text {beg }}-V_{\text {end }} / n\right)^{2} \cdot \varrho / 2=1 / 3 \cdot \varrho \cdot(\Delta V)^{2} / 2$. Since there are $\mathrm{n}$ holes along the pipeline, the total pressure loss on the local resistances will be $\sum \Delta p_{l}=1 / 3 n \cdot\left(V_{\text {beg }}-V_{\text {end }}\right)^{2} \cdot \varrho / 2$. As a result of the calculation, it was 
obtained the distribution of pressures and flow rates at the time of full pneumatic inflation.

Based on the schematic diagram and the results of hydraulic calculation, the mass of the pneumatic de-icing system was calculated. The mass of pipelines is $S=\pi\left(D^{2}-d^{2}\right) / 4 \cdot L \cdot \rho=11,6 \mathrm{~kg}$, where $L=73 \mathrm{~m}$ is the total pipeline length; $D=20 \mathrm{~mm}$ is the outer pipeline diameter; $d=18 \mathrm{~mm}$ is the inner pipeline diameter; $\rho=2700 \mathrm{~kg} / \mathrm{m}^{3}$ is the aluminum density. The mass of the pipeline was multiplied by 1,2 in order to take into account mass of attaching parts. The total mass of the pipe installation is $13,9 \mathrm{~kg}$. The total boot length is $34,3 \mathrm{~m}$. The specific mass of one boot meter is $1,5 \mathrm{~kg} / \mathrm{m}$. Therefore, the total boot mass is $51,5 \mathrm{~kg}$. The mass of each unit of the pneumatic de-icing system is shown in table 2 .

Table 2.

\begin{tabular}{|l|c|c|c|c|c|}
\hline No. & $\begin{array}{c}\text { two-position } \\
\text { valve }\end{array}$ & $\begin{array}{c}\text { throttle } \\
\text { valve }\end{array}$ & $\begin{array}{c}\text { reverse } \\
\text { valve }\end{array}$ & $\begin{array}{c}\text { safety } \\
\text { valve }\end{array}$ & $\begin{array}{c}\text { Vacuum } \\
\text { pump }\end{array}$ \\
\hline $\begin{array}{l}\text { Number of units } \\
\text { Total mass, } \mathrm{kg}\end{array}$ & 3 & 1 & 5 & 1 & 1 \\
\hline
\end{tabular}

The mass of the control system should not exceed $2,5 \mathrm{~kg}$.

The total mass of the pneumatic de-icing system is $80.0 \mathrm{~kg}$. The mass of the de-icing system on the AN-140 is $110.0 \mathrm{~kg}$.

\section{Conclusion}

Cyclic pneumatic de-icing system has significant advantages for regional aircrafts. It is safe, reliable and easy to operate. The analysis and the conducted calculations indicate its effectiveness and low mass.

\section{Literature}

1. Баранов А. М., Мазурин Н. И., Солонин С. В., Янковский И. А. Авиационная метеорология. - Л.: Гидрометеоиздат, 1966 - 281 с.

2. Мещзерякова Т. П. Проектирование систем защиты самолетов и вертолетов. - М.: Машиностроение, 1977.

3. Почекаев Д. Ю. Перечисление наиболее важных факторов при обледенении ЛА, [електронний ресурс]. - Режим доступу: www/URL: http://www.rusnauka.com/2. SND 2007/ Tecnic/ 19111.doc.htm.

4. Тенишев Р. X. Противообледелительные системы летательных аппаратов - М.: Машиностроение, 1967. - 320 с.

5. Трунов О. К. Обледенение самолетов и средства борьбы с ним - М.: Машиностроение, 1965. - 241 с.

6. Addy H. E. Jr. Ice accretions and icing effects for modern airfoils // NASA TP-2000-210031, $2000-285$ p. 
7. Aircraft accident report in-flight icing encounter and loss of control Simmons airlines, D.B.A. American Eagle flight 4184 Avions de transport regional (ATR) model 72-212, n 401 Amroselawn, Indiana October 31, 1994, National Transportation Safety Board, Washington, D.C. 20594 - 336 p.

8. Aircraft accident report in-flight icing encounter and uncontrolled collision with terrain Comair flight 3272 Embraer EMB-120RT, N265CA Monroe, Michigan January 9, 1997 National Transportation Safety Board, Washington, D.C. $20594-225$ p.

9. Aircraft Icing Handbook // Civil Aviation Authority, 2000 - 97 p.

10. Bragg M. B., Broeren A. P., Blumenthal L. A. Iced-airfoil aerodynamics // Progress in Aerospace Sciences 41, 2005, p. 323-362.

11. Bragg M. B., Loth E. Effects of large-droplet ice accretion on airfoil and wing aerodynamics and control // DOT/FAA/AR-00/14, $2000-176 \mathrm{p}$.

12. Busch G. T., Bragg M. B. Experimental study of full-scale iced-airfoil aerodynamic performance using sub-scale simulations // AIAA Paper 2009-4264 $-30 \mathrm{p}$.

13. Hiltner $D$. $W$. An Investigation of the Tailplane Aerodynamics and Aircraft Dynamics of the Ice Contaminated Tailplane Stall Phenomenon, Ph. D. Dissertation, Department of Aerospace, Aviation, and Applied Mechanics, The Ohio State University, Columbus, OH, 1998.

14. Lyncha F. T., Khodadoust A. Effects of ice accretions on aircraft aerodynamics // Progress in Aerospace Sciences 37, 2001 - p. 669-767.

15. Raps D., Jung S., Strobl T. Comparative evaluation of icing on aerodynamic surfaces // 28-th International congress of the aeronautical sciences, 2012 $6 \mathrm{p}$.

16. Ratvasky T. P. \& Ranaudo, R. J. Icing Effects on Aircraft Stability and Control Determined from Flight Data, Preliminary Results, AIAA-93-0398, NASA TM 105977, 1993.

17. Ratvansky T. P., Barnhard B. P., Lee S. Current methods modeling and simulating icing effect on aircraft performance, stability, control // J. Aircraft, 2010, v. 47, N 1 - p. 201-211.

18. Recommendations for De-Icing / Anti-Icing Aeroplanes on the Ground // Association of European Airlines, August 2010 - 50 p.

19. Thomas P. Ratvasky and Judith Foss Van Zante In-Flight Aerodynamic Measurements of an Iced Horizontal Tailplane // NASA TM-1999-208902 AIAA-99-0638 - $15 \mathrm{p}$.

20. Thomas $P$. Ratvasky, Judith Foss Van Zante, and Alex Sim NASA/FAA Tailplane Icing Program: Flight Test Program NASA TP-2000-209908 DOT FAA AR-99-85 - 166 p. 